DOI 10.22460/jpmi.v1i3.415-426

\title{
ANALISIS KESULITAN SISWA DALAM PEMECAHAN MASALAH MATEMATIK SISWA SMP PADA MATERI TEOREMA PHYTAGORAS
}

\author{
Nissa Risma Mulyanti ${ }^{1}$, Nur Yani $^{2}$, Risma Amelia ${ }^{3}$ \\ 1,2,3 IKIP Siliwangi, Jl. Terusan Jenderal Sudirman, Cimahi, Jawa Barat, Indonesia \\ ${ }^{1}$ nissarisma15@gmail.com, ${ }^{2}$ yani4744@gmail.com, ${ }^{3}$ rismaamelia@ikipsiliwangi.ac.id
}

Diterima: 26 April 2018; Disetujui: 28 Mei 2018

\begin{abstract}
A This article an analysis of the results of the test about problem-solving mathematical of grade IX students of Junior High School. This analysis aims to know the kinds of difficulties experienced by students and to determine the level of problem-solving skills students in the mathematics of junior high school students in Cimahi City. The research method used is qualitative descriptive. The samples taken for this research are 37 students of class IX in one of junior high school in Cimahi City. Instrument test of the problem-solving ability of mathematics given as many as 5 item. The results of the analysis obtained based on written tests conducted is the level of ability problem-solving mathematics students in one of junior high school in Cimahi is still relatively low.
\end{abstract}

Keywords: Mathematical Problem-Solving

\begin{abstract}
Abstrak
Artikel ini merupakan analisis terhadap hasil test soal pemecahan masalah matematik siswa kelas IX Sekolah Menengah Pertama. Analisis yang dilakukan bertujuan untuk mengetahui jenis-jenis kesulitan yang dialami oleh siswa dan untuk mengetahui tingkat kemampuan pemecahan masalah matematik siswa SMP di Kota Cimahi. Metode penelitian yang digunakan adalah kualitatif deskriptif. Adapun sampel yang diambil untuk penelitian ini adalah 37 orang siswa kelas IX di salah satu SMP di Kota Cimahi. Instrumen tes kemampuan pemecahan masalah matematik yang diberikan sebanyak 5 butir soal. Hasil analisis yang diperoleh berdasarkan tes tertulis yang dilakukan adalah tingkat kemampuan pemecahan masalah matematik siswa di salah satu SMP di Kota Cimahi masih tergolong rendah.
\end{abstract}

Kata Kunci: Pemecahan Masalah Matematis

How to cite: Mulyanti, N. R., Yani, N., \& Amelia, R. (2018). Analisis Kesulitan Siswa dalam Pemecahan Masalah Matematik Siswa SMP pada Materi Teorema Phytagoras. JPMI - Jurnal Pembelajaran Matematika Inovatif, 1 (3), 415-426.

\section{PENDAHULUAN}

Proses pemecahan masalah matematik merupakan salah satu kemampuan dasar matematik yang harus dikuasai siswa Sekolah Menengah (Hidayat \& Sariningsih, 2018). Pentingnya pemilihan kemampuan tersebut tercermin dari pernyataan Branca (Hendriana \& Soemarmo, 2014) bahwa pemecahan masalah matematik merupakan salah satu tujuan penting dalam pembelajaran matematika bahkan proses pemecahan masalah matematik merupakan jantungnya matematika.

Demikian pula pentingnya pemilikan kemampuan pemecahan masalah sejalan dengan pendapat berapa pakar. Cooney (Hendriana \& Soemarmo, 2014) mengemukakan bahwa 
pemilikan kemampuan pemecahan masalah membantu siswa berpikir analitik dalam mengambil keputusan dalam kehidupan sehari-hari dan membantu meningkatkan kemampuan berpikir kritis dalam menghadapi situasi baru. Branca (Hendriana \& Soemarmo, 2014) mengemukakan bahwa pemecahan masalah matematik mempunyai dua makna yaitu sebagai suatu pendekatan pembelajaran dan sebagai kegiatan atau proses dalam melakukan doing math.

Menurut Pimta (Khomsiatun \& Retnawati, 2015), Pemecahan masalah bukan hanya menjadi tujuan dari pembelajaran matematika, tetapi merupakan inti dalam pembelajaran matematika. Siswa yang sering dilatih dan dibiasakan dalam menyelesaikan atau memecahkan permasalahan matematika, kemampuan berpikirnya akan berkembang, selain kemampuan berpikirnya yang berkembang, kemampuan dasar dalam menyelesaikan masalah metematika pun akan berkembang, tetapi bukan hanya dalam menyelesaikan permasalahan matematika saja, namun dalam menyelesaikan permasalahan dalam kehidupan sehari-hari pun mereka dapat menyelesaikannya tanpa kendala (Wahyu, 2014).

Menurut Supriatna (Sari, 2015) memberikan gambaran bahwa soal - soal pemecahan masalah belum dikuasai oleh siswa. Hal ini terlihat dari jawaban siswa SMPN di Sumedang siswa yang mampu menjawab benar adalah $25,70 \%$. Siswa SMAN di Sumedang mampu menjawab soal dengan benar adalah 36,6\%. Jawaban mahasiswa STKIP di Jawa Barat yang mampu menjawab benar soal pemecahan masalah luas daerah segitiga adalah 38,4\%. Berdasarkan jumlah persentase tersebut, dapat ditarik kesimpulan bahwa kemampuan pemecahan masalah matematis siswa SMP hingga Universitas masih tergolong rendah.

Tidak dipungkiri matematika menjadi salah satu mata pelajaran dengan tingkat kesulitan belajar yang paling banyak dialami siswa. Oleh karena itu perlu penelusuran lebih dalam terhadap apa saja hambatan belajar siswa sehingga mengalami kesulitan mengerjakan soal matematika, terutama pada soal pemecahan masalah.

Menyikapi hal tersebut maka penulis melakukan studi pendahuluan untuk mengetahui kesulitan siswa dalam kemampuan pemecahan masalah matematik siswa SMP di salah satu sekolah di Kota Cimahi pada materi teorema phytagoras.

\section{METODE}

Penelitian yang dilakukan tergolong dalam penelitian deskriptif kualitatif yang bertujuan untuk mendeskripsikan kesalahan siswa dalam menyelesaikan soal teorema phytagoras dilihat dari tingkat kemampuan pemecahan masalah matematik siswa SMP. Data penelitian ini berupa jawaban tertulis yang diperoleh dari tes yang dilakukan. Sampel dari penelitian ini adalah 37 orang siswa kelas IX-C di salah satu SMP di Kota Cimahi. Adapun instrumen yang diberikan kepada siswa sebanyak 5 butir soal dengan bentuk uraian. Instrumen yang digunakan adalah instrumen yang sudah di uji coba oleh peneliti sebelumnya yaitu Nurlaelasari (2016), instrumen tersebut merupakan instrumen yang sudah di uji validitas, reliabilitas, indeks kesukaran serta daya pembedanya. 


\section{HASIL DAN PEMBAHASAN}

\section{Hasil}

Penelitian ini dilakukan pada 37 orang siswa di kelas IX-C. Berikut ini persentase jawaban siswa tiap butir soal yang disajikan pada Tabel 1 .

Tabel 1. Persentase Jawaban Siswa Tiap Butir Soal

\begin{tabular}{ccccc}
\hline \multirow{2}{*}{$\begin{array}{c}\text { Nomor } \\
\text { Soal }\end{array}$} & $\begin{array}{c}\text { Memahami } \\
\text { Masalah }\end{array}$ & $\begin{array}{c}\text { Merencanakan } \\
\text { Penyelesaian }\end{array}$ & $\begin{array}{c}\text { Melakukan } \\
\text { Perhitungan }\end{array}$ & $\begin{array}{c}\text { Memeriksa } \\
\text { Kembali }\end{array}$ \\
\cline { 2 - 5 } 1 & $84 \%$ & $95 \%$ & $84 \%$ & $56 \%$ \\
2 & $80 \%$ & $88 \%$ & $73 \%$ & $45 \%$ \\
3 & $78 \%$ & $80 \%$ & $59 \%$ & $28 \%$ \\
4 & $79 \%$ & $29 \%$ & $7 \%$ & $0 \%$ \\
5 & $28 \%$ & $41 \%$ & $26 \%$ & $3 \%$ \\
\hline Persentase & $55 \%$ & $67 \%$ & $44 \%$ & $26 \%$ \\
Keseluruhan & & & & \\
\hline
\end{tabular}

\section{Pembahasan}

Dalam menyelesaikan masalah atau dalam pemecahan masalah, terdapat beberapa kesalahan yang siswa lakukan dalam proses pemecahan masalah tersebut. Diantaranya: 1) kesalahan fakta, dimana siswa kurang mampu menyampaikan makna soal, 2) kesalahan konsep, dimana siswa kurang mampu menerapkan konsep dengan materi yang terkait, 3) kesalahan prinsip, dimana siswa tidak memperhatikan prasyarat untuk menggunakan rumus, atau teorema yang terkait dengan materi, 4) kesalahan operasi, dimana siswa melakukan langkah-langkah yang kurang tepat untuk penyelesaian dan kurang mampu memanipulasi langkah-langkah penyelesaian (Widodo, 2013).

Berikut ini adalah pembahasan mengenai analisis kemungkinan kesulitan yang dialami siswa sehingga melakukan kesalahan dalam jawaban dari soal yang diberikan.

a. Analisis Soal Nomor 1

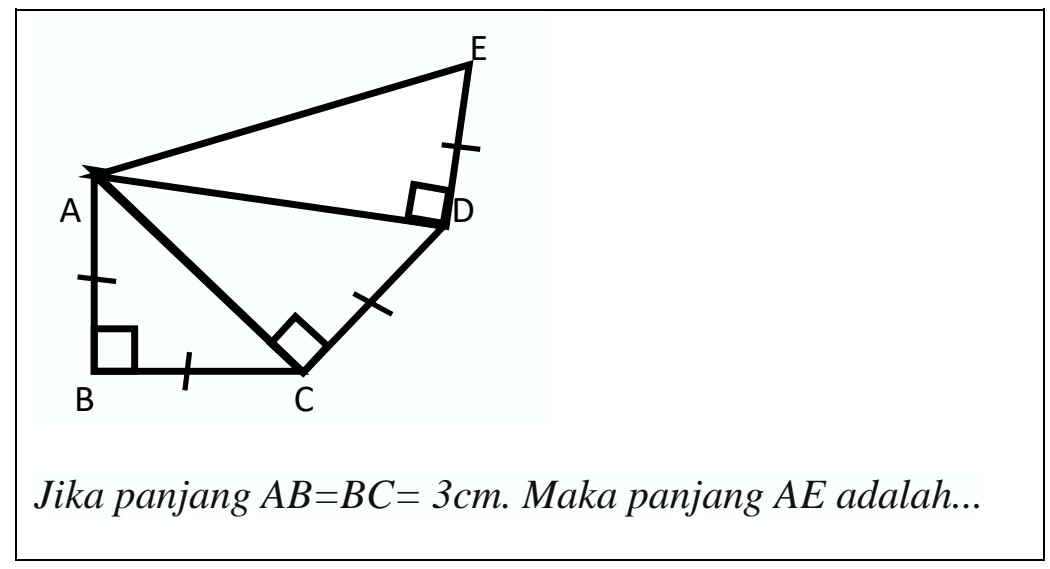

Gambar 1. Soal Nomor 1 


\section{Jawaban siswa 1:}

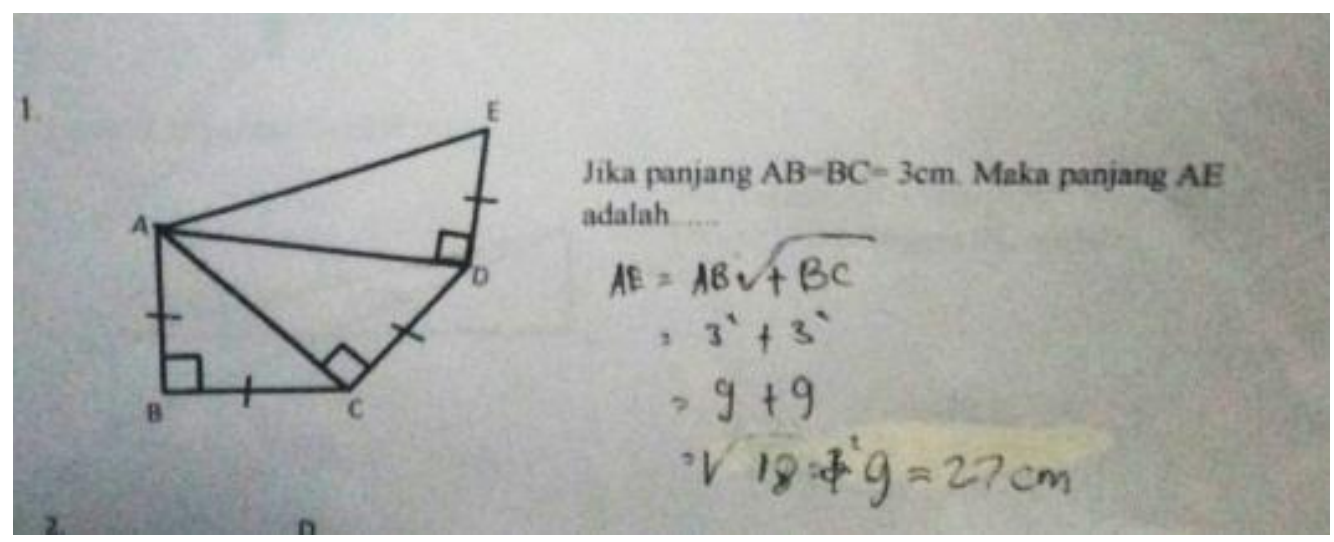

Gambar 2. Kesalahan Jawaban Siswa Soal Nomor 1

\section{Jawaban siswa 2:}

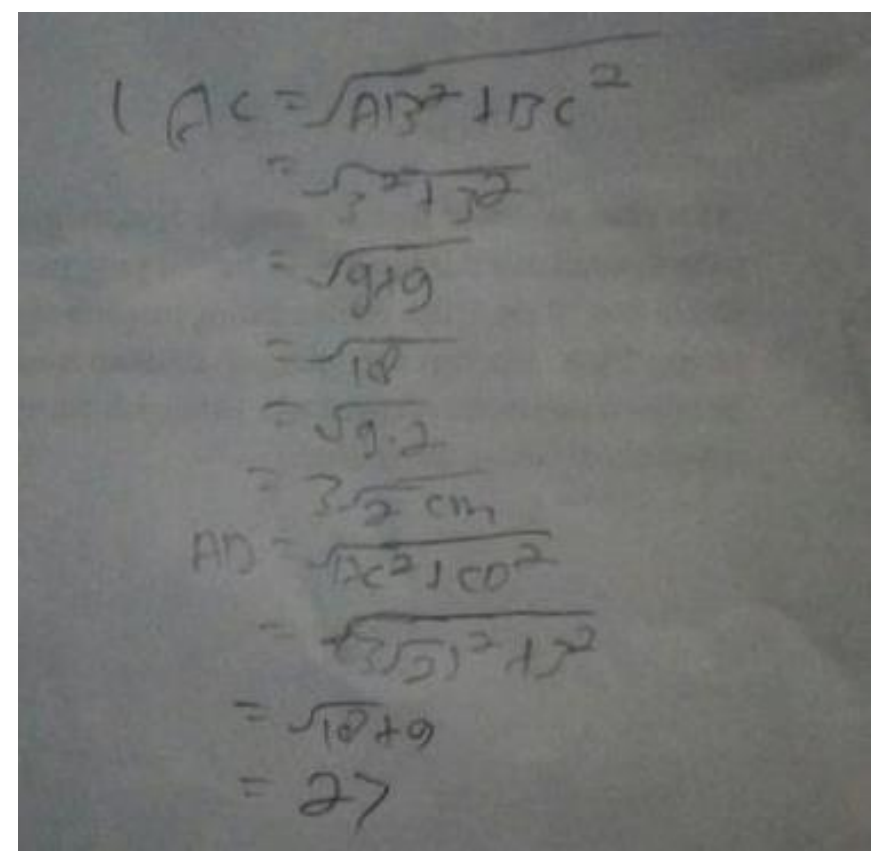

Gambar 3. Kesalahan Jawaban Siswa Soal Nomor 1

Kemungkinan kesulitan yang dialami siswa, sehinggga mengakibatkan kesalahan menjawab yaitu: siswa kurang menguasi konsep atau prasyarat mengenai teorema phytagoras, siswa kurang memahami konsep atau perhitungan bilangan yang terdapat pada tanda akar, kurang teliti dalam perhitungan.

kebanyakan siswa mampu mengerjakan soal nomor 1, tetapi ada saja jawaban siswa yang memberikan jawaban tidak sesuai dengan harapan. Seperti, kurang teliti dalam perhitungan dan kurang memahami perhitungan bilangan yang terdapat pada tanda akar kuadrat.

Jadi, dapat disimpulkan bahwa siswa kurang teliti dan perhitungan yang mereka lakukan,kurangnya kemampuan dalam perhitungan dalam akar kuadrat, dan untuk penulisan rumus teorema phytagoras masih ada yang kurang tepat, sehingga hasil akhir yang dapat kurang tepat 
b. Analisis soal nomor 2:

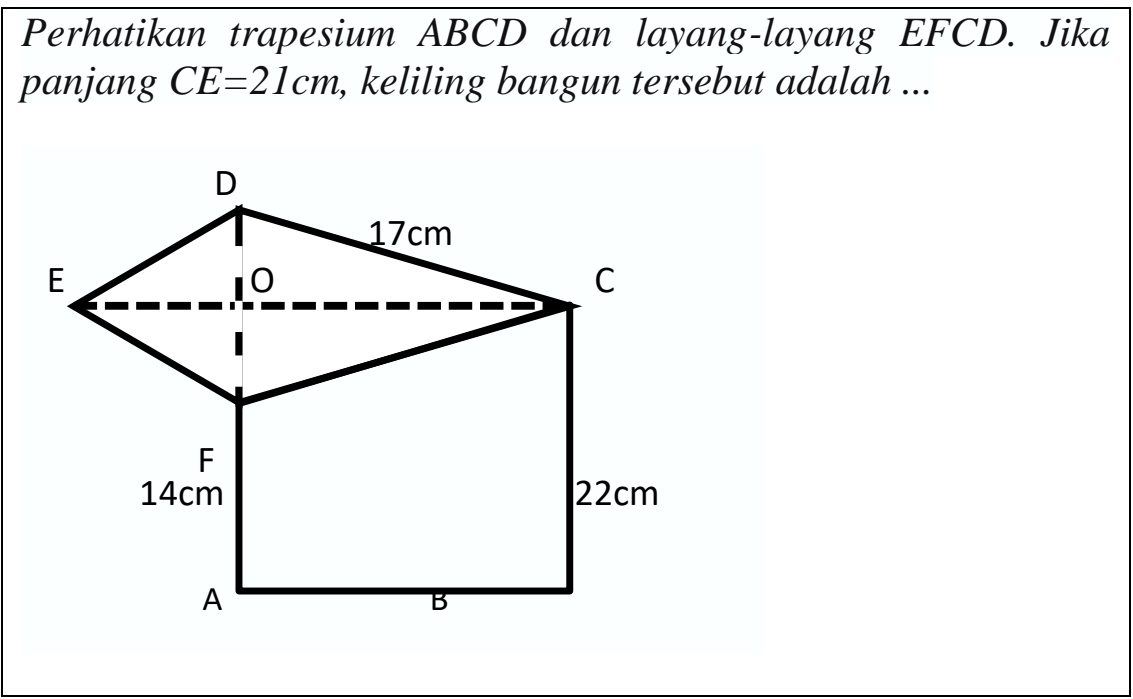

Gambar 4. Soal Nomor 2

\section{Jawaban siswa 1:}

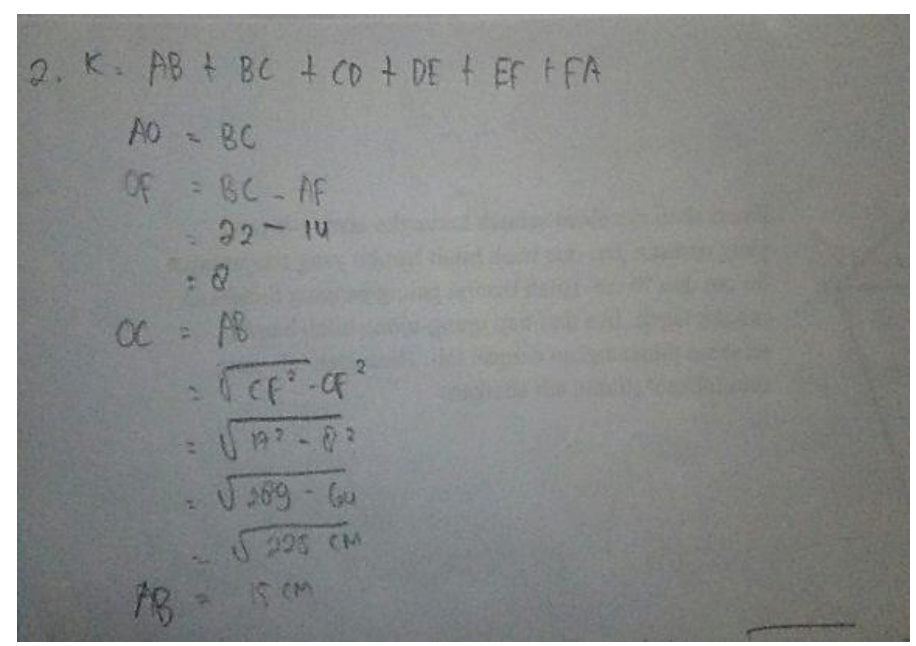

Gambar 5. Kesalahan Jawaban Siswa Soal Nomor 2

\section{Jawaban siswa 2:}

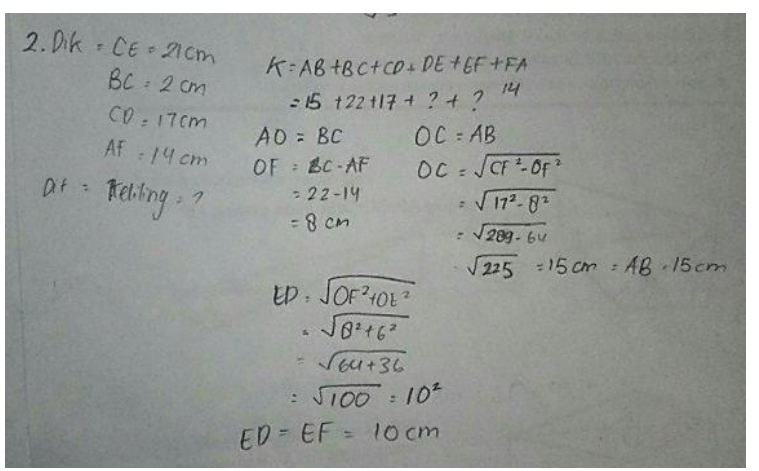

Gambar 6. Kesalahan Jawaban Siswa Soal Nomor 2 
Kemungkinan kesulitan yang dialami siswa, sehingga mengakibatkan kesalahan menjawab yaitu: siswa kurang menguasai konsep atau prasyarat mengenai teorema phytagoras dan kesebangunan, kurang teliti dalam perhitungan, siswa kurang terampil dalam mengaitkan dari satu situasi ke situasi yang lainnya.

Dari beberapa contoh pengerjaan siswa, kebanyakan siswa hanya menyelesaikan sebagian dari proses yang harusnya mereka lakukan, sehingga tujuan dari apa yang mereka akan cari tidak terpenuhi atau hasil akhirnya tidak didapatkan. Hal itu dikarenakan siswa kurang terampil dalam mengaitkan informasi yang mereka dapatkan dari soal sehingga rencana penyelesaiannya pun kurang tepat.

Jadi, dapat disimpulkan bahwa siswa kurang mampu mengatikan dari satu situasi ke situasi lainnya, kurang menguasi konsep atau prasyarat mengenai teorema phytagoras dengan baik, serta kurangnya kemampuan merencanakan penyelesaian dari persoalan yang diberikan masih tergolong kurang.

c. Analisis soal nomor 3:

Kebun Pak Suhud berbentuk persegi panjang yang memiliki panjang 15 $m$ dan luasnya $120 \mathrm{~m}^{2}$. Pak Suhud ingin sekali menghitung setengah dari diagonal kebun tersebut karena ia ingin menancapkan tiang bendera tepat di tengah kebunnya. Maka dari itu ia harus menghitung panjang diagonal kebunnya. Cukup, kurang atau berlebihkah data tersebut agar Pak Suhud mengetahui setengah dari panjang diagonal kebunnya tersebut? Jelaskan jawabanmu!

\section{Gambar 7. Soal Nomor 3}

\section{Jawaban siswa 1:}

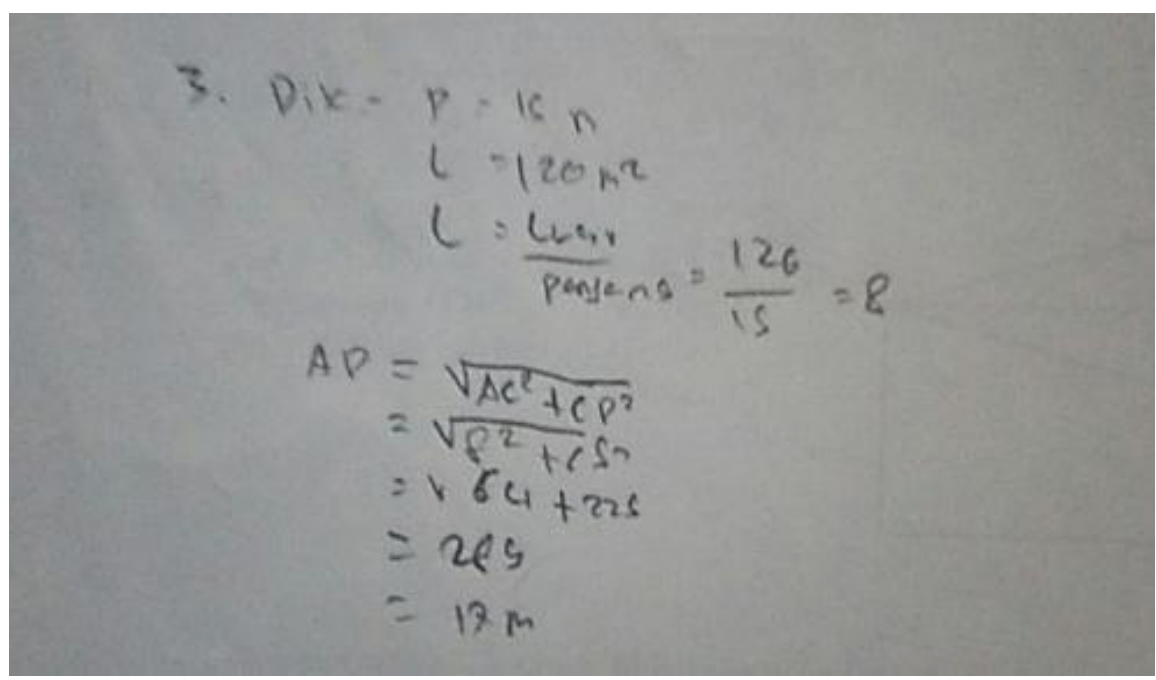

Gambar 8. Kesalahan Jawaban Siswa Soal Nomor 3 
Jawaban siswa 2:

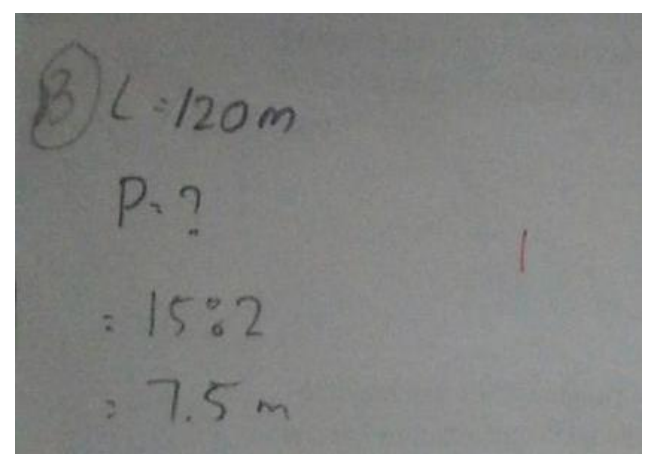

Gambar 9. Kesalahan Jawaban Siswa Soal Nomor 3

\section{Jawaban siswa 3:}

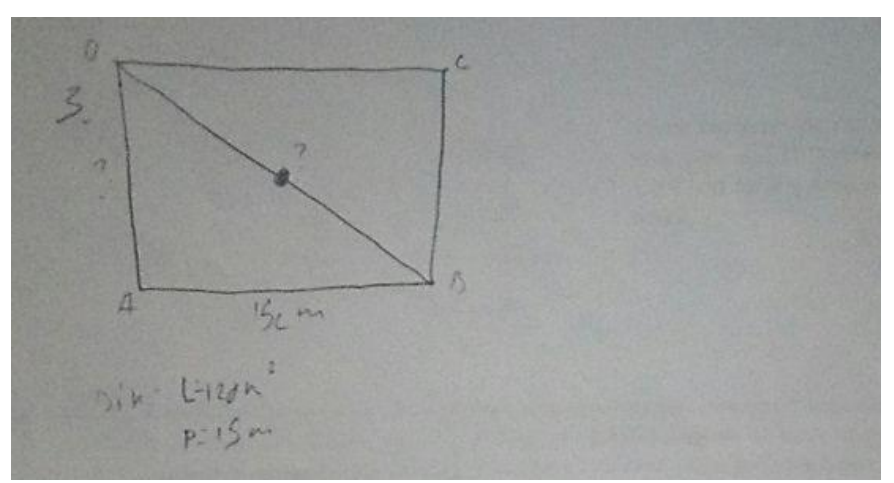

Gambar 10. Kesalahan Jawaban Siswa Soal Nomor 3

\section{Jawaban siswa 4:}

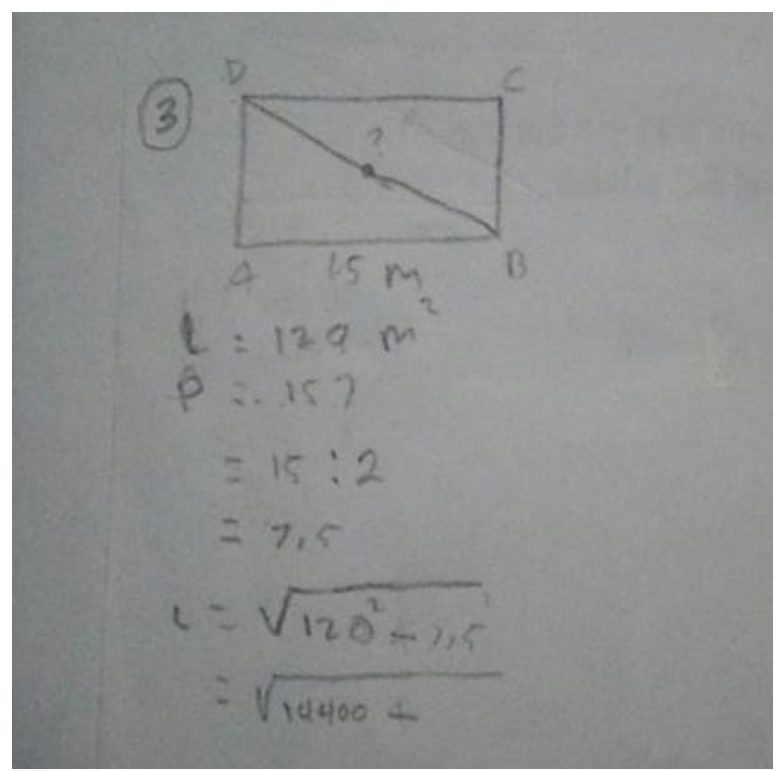

Gambar 11. Kesalahan Jawaban Siswa Soal Nomor 3

Kemungkinan kesulitan yang dialami siswa, sehingga mengakibatkan kesalahan menjawab yaitu: siswa kurang memahami kalimat matematika yang terdapat pada soal cerita, kurang memahami apa yang ditanyakan didalam soal, siswa kurang menguasai konsep atau prasyarat 
mengenai teorema phytagoras, kurang teliti dalam perhitungan, siswa kurang mampu menggunakan proses yang tepat dalam penyelesaian, siswa kurang terampil dalam mengaitkan dari satu situasi ke situasi yang lainnya.

Soal nomor tiga merupakan soal yang menggunakan perhitungan sederhana dalam penyelesaiannya. Dari beberapa contoh hasil pengerjaan siswa, letak kesalahan terbanyak adalah kurang memahami apa yang ditanyakan pada soal cerita tersebut, sehingga jawaban akhir yang mereka dapat kurang tepat atau tidak sesuai dengan apa yang ditanyakan.

Jadi, dapat disimpulkan bahwa pemahaman siswa dalam memahami masalah, merencanakan perhitungan, dan melakukan perhitungan untuk menyelesaiakan persoalan masih tergolong kurang.

d. Analisis soal nomor 4:

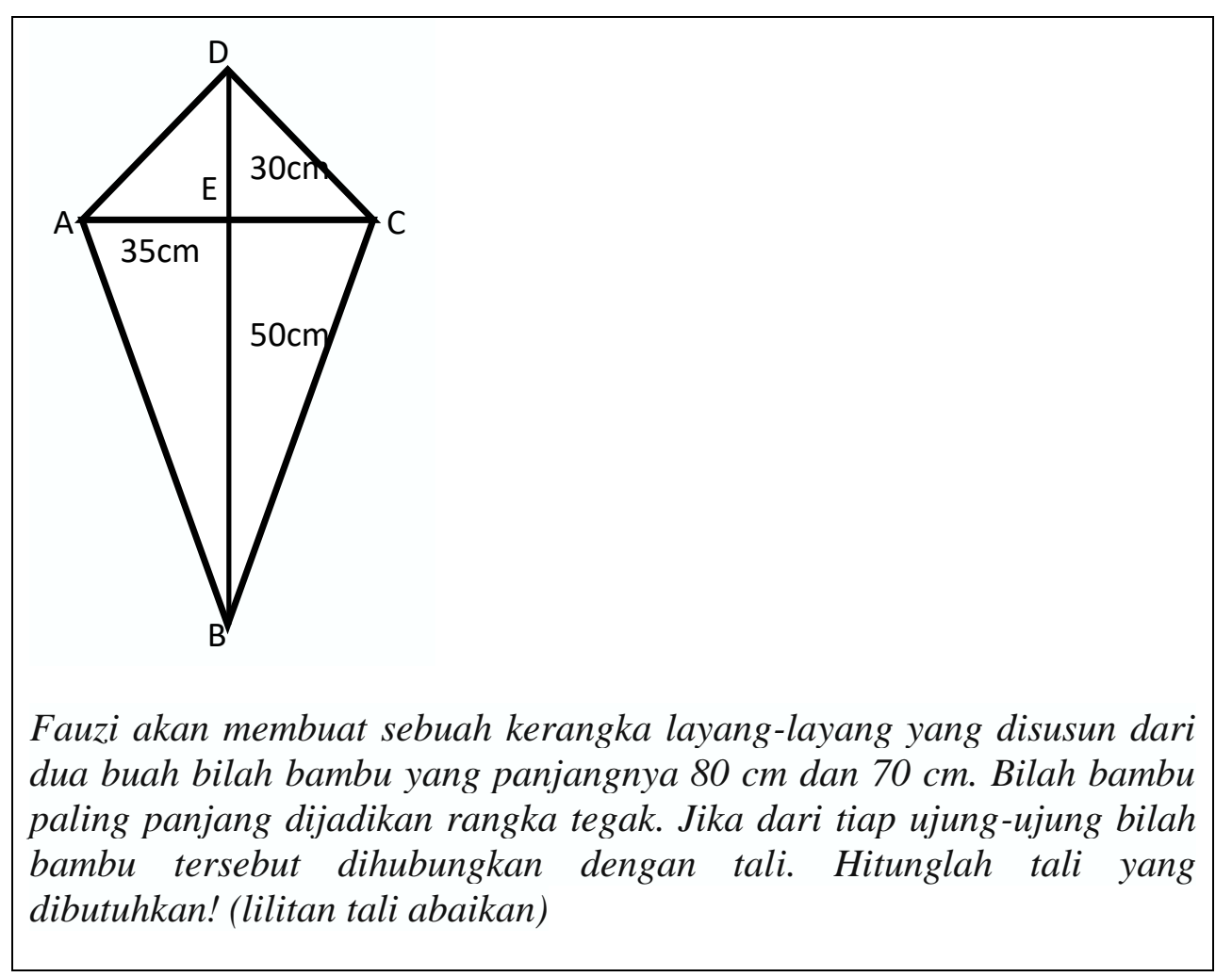

Gambar 12. Soal Nomor 4

\section{Jawaban siswa 1:}

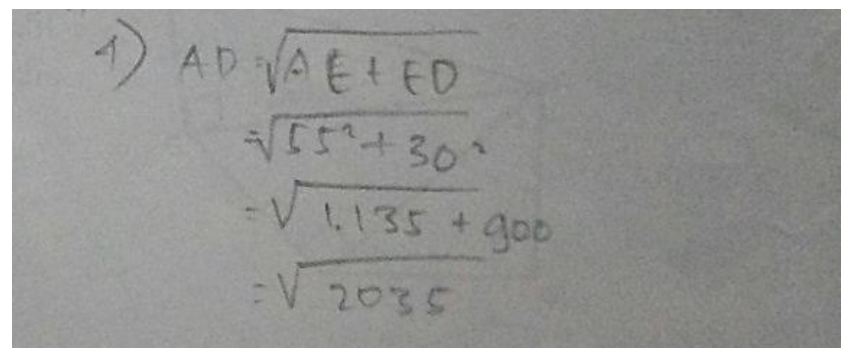

Gambar 13. Kesalahan Jawaban Siswa Soal Nomor 4 
Kemungkinan kesulitan yang dialami siswa, sehingga mengakibatkan kesalahan menjawab yaitu: siswa kurang memahami kalimat matematika yang terdapat pada soal cerita, kurang memahami apa yang ditanyakan didalam soal, siswa kurang menguasai konsep atau prasyarat mengenai teorema phytagoras, siswa kurang mampu menggunakan proses yang tepat dalam penyelesaian

Berdasarkan beberapa contoh hasil pengerjaan siswa, letak kesalahan terbanyak adalah siswa kurang terampil dan mengaitkan dari satu situasi ke situasi yang lainnya dan kurang memahami masalah yang diberikan.

Jadi, dapat disimpulkan bahwa pemahaman siswa dalam memahami masalah, merencanakan perhitungan, dan melakukan perhitungan untuk menyelesaikan persoalan masih tergolong kurang.

e. Analisis soal nomor 5:

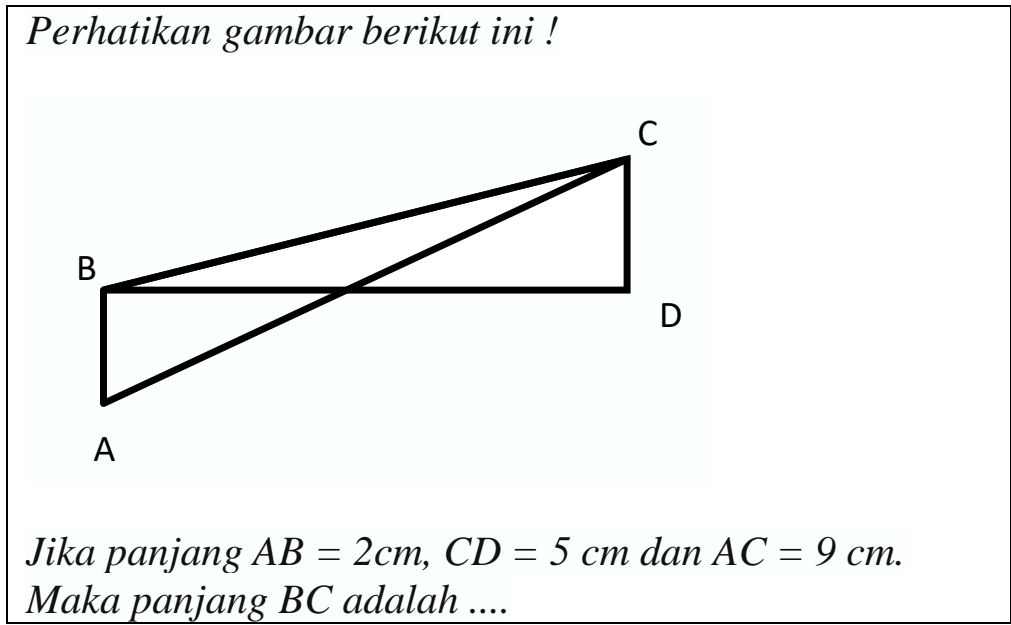

Gambar 14. Soal Nomor 5

\section{Jawaban siswa 1:}

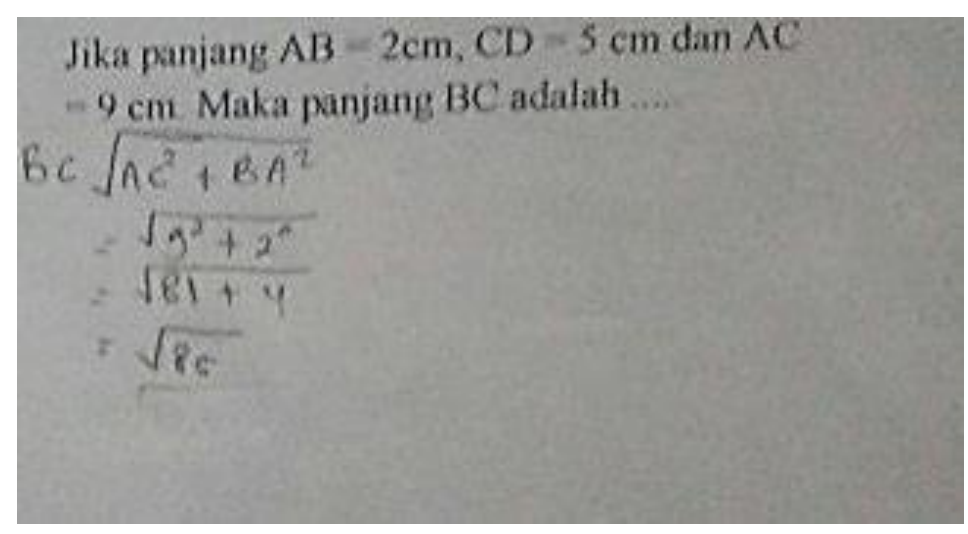

Gambar 15. Kesalahan Jawaban Siswa Soal Nomor 5 


\section{Jawaban siswa 2:}

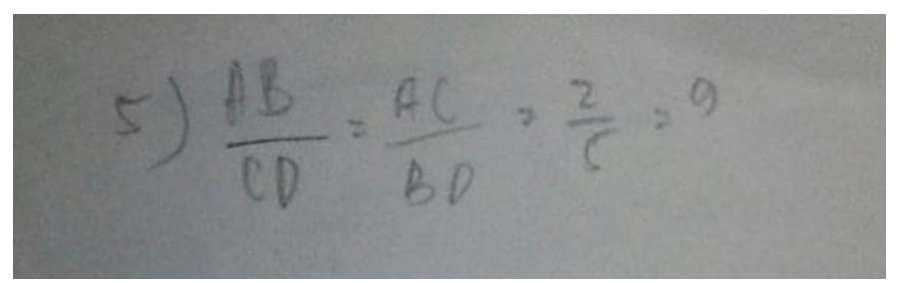

Gambar 16. Kesalahan Jawaban Siswa Soal Nomor 5

\section{Jawaban siswa 3:}

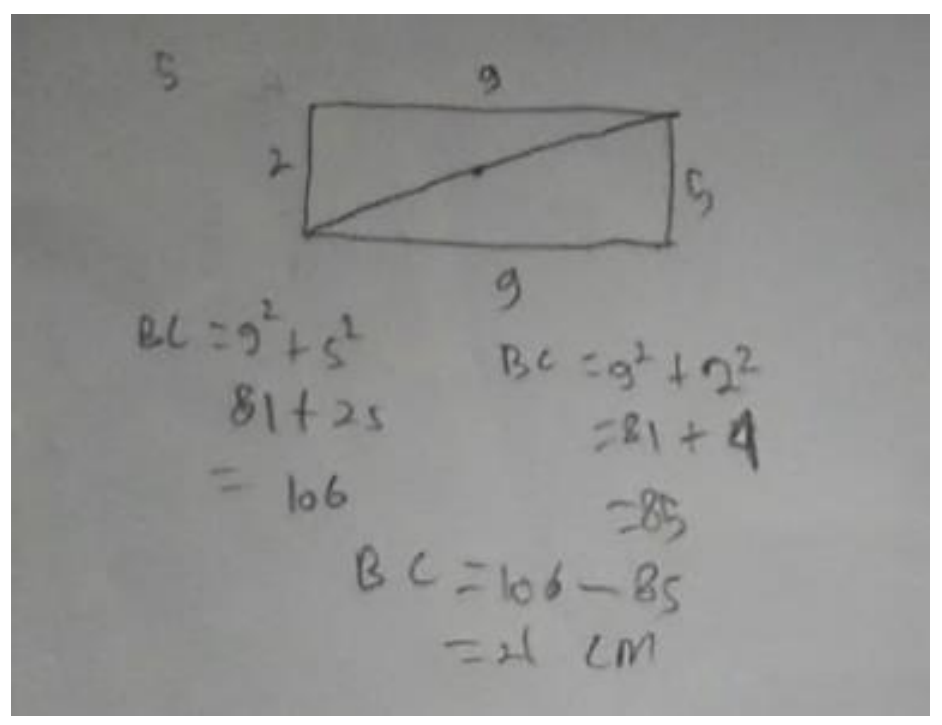

Gambar 17. Kesalahan Jawaban Siswa Soal Nomor 5

Kemungkinan kesulitan yang dialami siswa, sehingga mengakibatkan kesalahan menjawab yaitu: siswa kurang memahami permasalahan, siswa kurang menguasai konsep atau prasyarat mengenai teorema phytagoras, siswa kurang mampu menggunakan proses yang tepat dalam penyelesaian, siswa kurang terampil dalam mengaitkan dari satu situasi ke situasi yang lainnya.

Berdasarkan beberapa contoh hasil pengerjaan siswa, letak kesalahan terbanyak adalah siswa kurang terampil dan mengaitkan dari satu situasi ke situasi yang lainnya dan kurang memahami masalah yang diberikan. Dengan demikian pemahaman siswa dalam memahami masalah, merencanakan perhitungan, untuk menyelesaikan persoalan masih tergolong kurang.

\section{KESIMPULAN}

Berdasarkan pada hasil dan pembahasan, dapat kita simpulkan beberapa kesalahan siswa dalam menjawab soal pemecahan masalah matematik yakni: (1) Kurangnya pemahaman siswa dalam memahami persoalan matematik, terutama pada soal berbentuk cerita; (2) Kurangnya penguasaan konsep atau prasyarat mengenai teorema phytagoras; (3) Dalam merencanakan penyelesaian atau menafsirkan solusi masih kurang, dikarenakan kurang 
memahami persoalan yang diberikan; (4) Dalam melakukan perhitungan, siswa kurang teliti dalam perhitungan yang mereka lakukan dan proses yang mereka gunakan untuk menyelesaikan persoalan masih kurang tepat, yang merupakan akibat dari kurangnya kemampuan memahami masalah, dan merencanakan atau menafsirkan solusi yang akan digunakan; dan (5) Kurang mampu dalam mengaitkan dari satu situasi ke situasi lainnya. Selain itu, berdasarkan hasil analisis menunjukan bahwa siswa kelas IX di Kota Cimahi masih memiliki tingkat kemampuan pemecahan masalah matematik yang tergolong rendah pada materi teorema Phytagoras.

\section{DAFTAR PUSTAKA}

Hendriana, H., \& Soemarmo, U. (2014). Penilaian Pembelajaran Matematika. Bandung: Refika Aditama.

Hidayat, W., \& Sariningsih, R. (2018). Kemampuan Pemecahan Masalah Matematis dan Adversity Quotient Siswa SMP Melalui Pembelajaran Open Ended. JNPM (Jurnal Nasional Pendidikan Matematika), 2(1), 109-118.

Khomsiatun, S., \& Retnawati, H. (2015). Pengembangan Perangkat Pembelajaran dengan Penemuan Terbimbing untuk Meningkatkan Kemampuan Pemecahan Masalah. Jurnal Riset Pendidikan Matematika, 2(1), 92-106.

Nurlaelasari, F. (2016). Pengaruh Pendekatan Problem Based Learning Terhadap Kemampuan Pemecahan Masalah Matematik Siswa MTS di Kota Cimahi. Skripsi STKIP Siliwangi, Bandung: Tidak diterbitkan.

Sari, N. M. (2015). Meningkatkan Kemampuan Pemecahan Masalah Matematis dengan Metode Eksplorasi. Journal Mathematics Education Alphamath, 1(1), 31-43.

Wahyu, H. (2014). The Implementation of MEAs Instruction to Students' Mathematics Problem Solving and Connecting Ability. In Proceeding of International Conference on Research, Implementation and Education of Mathematics and Sciences 2014. Yogyakarta State University.

Widodo, S. A. (2013). Analisis Kesalahan dalam Pemecahan Masalah Divergen Tipe Membuktikan pada Mahasiswa Matematika. Jurnal Pendidikan Dan Pengajaran, 46(2), 106-113. 
426 Mulyanti, Yani, \& Amelia, Analisis Kesulitan Siswa dalam Pemecahan Masalah ... 